\title{
World-wide every fifth vascular plant species is or was used as medicinal or aromatic plant ${ }^{1}$
}

\author{
Rüdiger Wittig, Theo Dingermann, Robert Sieglstetter, Yingzhong Xie, Adjima Thiombiano and Karen Hahn
}

Summary: It is common knowledge that plants have been the world-wide most important source of medicines and that they still play this role in developing countries. However, up to now, complete lists of medicinal and aromatic plants (MAP) exist for comparatively few countries. A review of all lists know to the authors reveals the following results:

A total of $20.7 \%$ of the plant species analyzed by either publications or own research are or were used as MAP. However, regarding single countries, the differences are considerably high. Absolutely leading the list are China (36.2 \%), Burkina Faso $(35.2 \%)$ and the Korean Republic $(34.5 \%)$. Also ahead of other countries or regions are the North of Benin (32.8\%) and the entire Pakistan (30.3\%). Still above average rank Great Britain (26.7 \%) and Nepal (23.3\%), while the figures for Bulgaria (21.0 \%), Germany (20.2 \%) and France (19.4\%) almost represent the average. Jordan (17.3 \%), Vietnam (17.1 \%), Sri Lanka (16.6\%), India (16.1\%) and Thailand (15.5\%) rank slightly beneath. Clearly below the average are the percentages of MAP for Hungary (12.2\%) and the USA (11.8 \%). The average numbers of MAP in the Philippines (9.5 \%) and Malaysia (7.7\%) fall far behind.

Calculated on a worldwide scale, every fifth plant can be regarded as MAP. This number matches that from Bulgaria, France and Germany. In northern Benin, Burkina Faso, Korea, China and Pakistan, however, every third plant is or was used as MAP, whereas in Hungary and the USA only every eighth plant can be regarded as MAP. This number drops even further for the Philippines ore Malaysia where only every tenth or thirteenth plant can be attributed to medicinal or aromatic use. These differences might be due to various factors.

A geographical component of the results is obvious: in most cases geographically close countries show similar percentages. A correlation between the total number of species and the fraction of those used as MAP cannot be confirmed. The countries with percentage of MAP > $30 \%$ in common show that they belong either entirely (Burkina Faso, Benin) or at least in their rural areas to the poorest countries of the world so that it is (was) impossible for the majority of the people to buy "modern" MAP. In those countries the number of traditional healers outnumbers largely the number of modern doctors. Therefore, the tradition of folk medicine was maintained until today. Additionally, China, Korea and partially Pakistan have a very old and well documented tradition of folk medicine. Due to this documentation even in areas where today "modern MAP" are used, the knowledge was not lost.

In neighboring countries or regions, which differ with respect to a more arid or a more humid climate, for the arid country (region) more MAPs are reported than for the humid one. The potential reasons for this phenomenon are discussed in the paper.

For many countries the percentage given for MAP in literature is too low. But even these low values represent a striking argument for the importance of a world-wide conservation of biodiversity.

Key words: biodiversity, ethnobotany, MAP, traditional medicine.

\section{A L'ÉCHELle MONDIALE LE 5ÈME des ESPÈCES de PLANTES VASCULAIRES EST OU A ÉTÉ UTILISÉ COMME PLANTE MÉDICINALE OU AROMATIQUE}

Résumé: Il est bien connu que des plantes ont été la source la plus importante des médicaments dans le monde entier et qu'elles jouent encore ce rôle dans les pays en voie de développement. Cependant, jusqu'à présent, les listes complètes des plantes médicinales et aromatiques (PAM) n'existent relativement que pour peu de pays. Un examen de toutes les listes connues des auteurs révèle les résultats suivants:

Un total de 20,7\% des espèces de plantes examinées soit à travers des publications ou de nos propres recherches sont ou ont été utilisés comme MAP. Toutefois, en considérant les pays individuellement, les différences sont considérablement importantes. En tête de liste se trouvent incontestablement la Chine (36,2\%), le Burkina Faso (35,2\%) et la République de Corée (34,5\%). Les autres pays ou régions qui se classent en tête sont le Nord-Bénin (32,8\%) et le Pakistan (30,3\%). Toujours au dessus du classement moyen se trouvent la Grande-Bretagne (26,7\%) et le Népal (23,3\%), alors que la Bulgarie $(21,0 \%)$, l'Allemagne $(20,2 \%)$ et la France $(19,4 \%)$ se retrouvent dans la catégorie moyenne. La Jordanie $(17,3 \%)$, le Vietnam $(17,1 \%)$, le Sri Lanka $(16,6 \%)$, l'Inde $(16,1 \%)$ et la Thaïlande $(15,5 \%)$ se classent légèrement en dessous. La Hongrie $(12,2 \%)$ et les Etats-Unis $(11,8 \%)$ présentent des pourcentages moyens en PAM nettement en dessous de la moyenne. Les nombres moyens de MAP en Philippines (9,5\%) et en Malaisie (7,7\%) sont loin derrière.

Les différences entre certains pays sont frappantes: calculé à l'échelle mondiale, chaque cinquième de plantes peut être considéré comme MAP. Ce nombre correspond à celui de la Bulgarie, de la France et de l'Allemagne. Cependant, dans le Bénin, le Burkina Faso, la Corée, la Chine et le Pakistan, chaque tiers (1/3) de plantes est ou a été utilisée comme PAM, alors dans la Hongrie et les États-Unis seulement chaque huitième (1/8) de plantes peut être considéré comme MAP. Ce nombre baisse davantage pour les Philippines ou la Malaisie, où seulement chaque dixième $(1 / 10)$ ou treizième $(1 / 13)$ de plantes peut être attribué à un usage médicinal ou aromatique. Ces différences pourraient être dues à divers facteurs comme:

Le caractère géographique des résultats est évident: dans la plupart des cas, les pays géographiquement proches affichent des pourcentages similaires. Une corrélation entre le nombre total d'espèces et la fraction de celles utilisées comme MAP ne peut être confirmée. Les pays ayant en commun le pourcentage de MAP> 30\% appartiennent soit entièrement (Burkina Faso, Bénin) ou au moins leurs zones rurales aux pays les plus pauvres du monde de sorte qu'il est (était) impossible pour la 
majorité de la population d'acheter les médicines "modernes". Dans ces pays, le nombre de tradipraticiens dépasse largement le nombre de médecins. Par conséquent, la tradition de la médecine folklorique a été maintenue jusqu'à nos jours. En outre, la Chine, la Corée et partiellement le Pakistan ont une tradition très ancienne et bien documentée de la médecine folklorique. Grâce à cette documentation, même dans les zones où aujourd'hui «les MAP modernes» sont utilisées, la connaissance n'est pas perdue.

Dans les pays ou régions voisines, différant par rapport à l'aridité ou à l’humidité du climat, plus de MAPs sont signalées dans les pays arides (régions) contrairement à ceux humides. Les raisons possibles de ce phénomène sont discutées dans l'article.

Pour de nombreux pays, le pourcentage donné des PAM dans la littérature est trop faible. Malgré tout, ces faibles valeurs indiquent clairement l'importance d'une conservation de la biodiversité à l'échelle mondiale.

Mots clés: biodiversité, ethnobotanicque, médecine traditionnelle, PAM

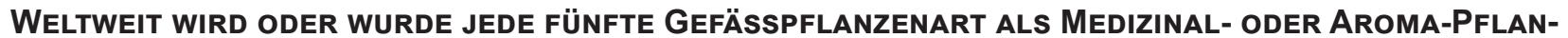 ZE GENUTZT}

Zusammenfassung: Es ist allgemein bekannt, dass Pflanzen früher weltweit die wichtigste Heilmittel-Quelle waren und es in Entwicklungsländern heute noch sind. Jedoch gibt es bisher nur für relativ wenige Länder eine komplette Liste der Medizin- und Aroma-Pflanzen (MAP). Eine Auswertung aller den Autoren bekannten Listen erbrachte folgende Resultate:

Insgesamt werden oder wurden 20,7 \% der in den ausgewerteten Arbeiten enthaltenen Arten als MAP genutzt. Bezüglich der einzelnen Länder bestehen jedoch große Unterschiede: Führend hinsichtlich des Anteils genutzter Arten sind China (36,2 \%), Burkina Faso (35,2 \%) und die Republik Korea (34,5 \%). Weit vorne liegen auch der Norden Benins (32,8 \%) sowie Pakistan (30,3 \%), noch über dem Durchschnitt rangieren Großbritannien (26.7\%) und Nepal (23.3 \%), während die Prozentzahlen von Bulgarien (21,0 \%), Deutschland (20,2 \%) und Frankreich (19,4 \%) ungefähr der Durchschnitt repräsentieren; Jordanien (17,3 \%), Vietnam (17,1 \%), Sri Lanka (16,6 \%), Indien (16,1 \%) und Thailand (15,5 \%) liegen knapp darunter. Klar unterdurchschnittlich sind die Zahlen für Ungarn (12,2 \%) und die USA (11,8 \%); die Philippinen (9,5 \%) und Malaysia (7,7 \%) liegen weit hinten.

Im weltweiten Durchschnitt hat also jede fünfte Gefäßpflanzenart MAP-Eigenschaften. In Benin, Burkina Faso, Korea, China und Pakistan trifft dies sogar für jede dritte Art zu, in Ungarn und USA dagegen nur für jede achte, auf den Philippinen und in Malaysia lediglich für jede zehnte bzw. dreizehnte. Diese auffälligen Unterschiede können verschiedene Ursachen haben.

Sofort sichtbar ist eine geografische Komponente: dicht benachbarte Länder zeigen in der Mehrzahl der Fälle ähnliche Werte. Dagegen kann keine Beziehung zwischen der Gesamtzahl der Arten und dem Anteil der MAP konstatiert werden. Allen Ländern mit hohen MAP-Prozenten ist gemeinsam, dass sie entweder vollständig oder wenigstens in ihren ländlichen Bereichen zu den ärmsten Regionen der Welt gehören (Burkina Faso, Benin) oder bis vor wenigen Jahrzehnten gehörten (China), so dass es der Mehrzahl der Bevölkerung unmöglich war, „moderne“ Arzneien zu kaufen. In diesen Ländern übertrifft oder übertraf bis vor kurzem die Zahl der traditionellen Heiler die der studierten Mediziner. Aus diesem Grunde hat die VolksMedizin bis heute überlebt. Zusätzlich existiert in China, Korea und teilweise auch in Pakistan eine gute Dokumentation der Volksmedizin, weshalb auch in Gebieten, in denen heute die „moderne“ Medizin Einzug gehalten hat, das Wissen um die traditionellen MAP nicht verloren gegangen ist.

In benachbarten Ländern oder Regionen, die sich bezüglich der Aridität bzw. Humidität des Klimas unterscheiden, ist der Anteil der MAP in den ariden Gebieten höher. Die vielfältigen potentiellen Erklärungen für dieses Phänomen werden im vorliegenden Aufsatz diskutiert.

Für mehrere Länder ist der in der Literatur zu findende Anteil an MAP zu niedrig. Aber selbst diese Werte bilden einen überzeugenden Beweis für die Wichtigkeit einer weltweiten Bewahrung der Biodiversität.

Schlagworte: Biodiversität, Ethnobotanik, MAP, traditionelle Medizin

\section{INTRODUCTION}

It is common knowledge that plants have been the worldwide most important source of medicines and that they still play this role in developing countries (SOFOwARA 1996; The delegates of the Conference on Traditional Medicine in ASEAM Countries 2010), particular in remote areas (e.g. Caniago \& Siebert 1998, Weckerle et al. 2005). But even in highly developed Western countries they have maintained a leading position as source of medicines as shown for the period of 1981-2002 by Newman et al. (2003). In Germany for example, $75 \%$ of the population regularly use some form of traditional complimentary and alternative medicine (Marstedt \& Moebus 2002), in Canada 70\% (Health Canada 2001) and in England 47\% (Thomas et al. 2001). Many reviews and comprehensive books documenting and explaining this importance exist (e.g. Prajapati et al. 2005; RaO et al. 2005; Bogers et al. 2006; KAYNe 2010). As there is no doubt that medicinal plants will be also very important for tomorrow's pharmacy (Lewis 2003; Craker \& Gardner 2006), it is of great interest, how many plants have already been used as pharmaceutical (medicinal and aromatic) plants up to now. In the following, we answer this question by a literature search combined with data from own investigations in West Africa (e.g. WitTig et al. 2000, 2002, 2009). The results will be an important contribution to the discussion on the importance of ecosystem services (see e.g. Costanza et al. 1997; Millenium Ecosystem Assessment 2005) and the value of biodiversity (e.g. BALMFORD et al. 2002; European Communities 2008). As collecting wild plants for pharmaceutical purposes is still very common in most regions of the Sudano-Sambesian zone, we consider our paper suitable for Flora et Vegetatio Sudano-Sambesica. 


\section{SOURCES AND METHODS}

Up to now, complete lists of medicinal and aromatic plants (MAP) exist only for comparatively few countries. Luckily these lists comprise some of the largest countries so that our question can be answered on a sufficiently broad basis. Nevertheless, we completed the available lists by own investigations.

The following sources and methods were used:

- Benin: results of an own intensive ethnobotanical research in the North of Benin were assumed to be valid for the whole country;

- Bulgaria: Hardalova et al. (1998);

- Burkina Faso: we conducted a detailed countrywide ethnobotanical research; in all parts of the country, healers and old women (the knowledge on MAP is particular passed on by women) were interviewed by using a standardised questionnaire; additionally we used the results of Nacoulma Ouedraogo (1996);

- China: YANG (2006);

- Germany: all species named as MAP in the Flora of Germany (OBERDORFER 2001) and all species listed in particular books on Germany's medicinal plants (WICHTL 2002, SCHÖNFELDER \& SCHÖNFELDER 2004, VAN WYK et al. 2004) in relation to the total species number in OBERDORFER (2001; aggregates were rated as one species);

- Great Britain and Ireland: all species listed by ALLEN \& HATFIELD (2004) in relation to the total number of native and naturalised species (based on ClaPHAM et al. 1993);

- India: JAIN \& DeFILLIPPS (1991);

- Jordania: Oran \& Ali-EISAwi (1998);

- Nepal: Hamilton \& RAdFord (2007);

- Pakistan: ZAHOOR (1997);

- USA: Moerman (1996);

- All other countries mentioned in Table 1: Schipmann et al. (2006).

The series médicine traditionelle et pharmacopée, edited in Paris by the Agence de Cooperation Culturelle et Technique (ACCT) which covers most francophone African countries (see LeJoly 1993) was not considered in the results, because we realized by the example of Benin (ADJANOHOun et al. 1989) that only well-known and often used species are represented.

\section{RESULtS}

A total of $20.7 \%$ of the plant species analyzed by either publications or own research are or were used as MAP. However, regarding single countries, the differences are considerably high. Absolutely leading the list are China (36.2 $\%)$, Burkina Faso (35.2 \%) and the Korean Republic (34.5 $\%)$. Also ahead of other countries are Benin (32.8\%) and Pakistan (30.3\%). Still above average rank Great Britain (26.7\%) and Nepal (23.3\%), while the figures for Bulgaria (21.0\%), Germany (20.2\%) and France (19.4\%) almost represent the average. Jordan (17.3\%), Vietnam (17.1\%), Sri Lanka (16.6 \%), India (16.1 \%) and Thailand (15.5 \%) rank slightly beneath. Clearly below the average are the percentages of MAP for Hungary (12.2 \%) and the USA (11.8 \%). The average numbers of MAP in the Philippines (9.5\%) and Malaysia (7.7 \%) fall far behind.

Table 1: Number of PAM in relation to the total number of plant species / Nombre de PAM par rapport au nombre total d'espèces de plantes / Anzahl der PAM im Verhältnis zur Gesamtzahl der Arten

\begin{tabular}{|l|l|l|l|}
\hline \multirow{2}{*}{ Country } & total & \multicolumn{2}{|l|}{ number of MAP } \\
\cline { 3 - 4 } & $\begin{array}{l}\text { vascular } \\
\text { plants }\end{array}$ & abso- & relative \\
& lute & \\
\hline Benin, Atakora region & 2807 & 921 & $32.8 \%$ \\
\hline Bulgaria & 3567 & 750 & $21.0 \%$ \\
\hline Burkina Faso & 1696 & 597 & $35.2 \%$ \\
\hline China, total & 35364 & 12807 & $36.2 \%$ \\
\hline China, NW & ca. 3900 & ca. 2300 & $58.9 \%$ \\
\hline Germany & 2475 & 501 & $20.2 \%$ \\
\hline France & 4630 & ca. 900 & $29.4 \%$ \\
\hline Great Britain* & 1503 & 402 & $26.7 \%$ \\
\hline Hungary & 2214 & 270 & $12.2 \%$ \\
\hline India & 18664 & ca. 3000 & $16.1 \%$ \\
\hline Jordan & ca. 2100 & 363 & $17.3 \%$ \\
\hline Korea (Rep. of) & 2898 & ca. 1000 & $34.5 \%$ \\
\hline Malaysia & ca. 15500 & ca. 1200 & $7.7 \%$ \\
\hline Nepal & 6973 & 1625 & $23.3 \%$ \\
\hline Pakistan & 4950 & ca. 1500 & $30.3 \%$ \\
\hline Philippines & 8931 & ca. 850 & $9.5 \%$ \\
\hline Sri Lanka & 3314 & ca. 550 & $16.6 \%$ \\
\hline Thailand & 11625 & ca. 1800 & $15.5 \%$ \\
\hline USA & 21641 & 2564 & $11.8 \%$ \\
\hline Vietnam & ca. 10500 & ca. 1800 & $17.1 \%$ \\
\hline total & $\mathbf{1 3 3 2 5 2}$ & $\mathbf{2 0 8 0 0}$ & $\mathbf{2 0 . 2 \%}$ \\
\hline & & & \\
\hline
\end{tabular}

*and Ireland

Sources: Benin: Sieglstetter (2002); Bulgaria: Hardalova et al. (1998); Burkina Faso: results of our own detailed countrywide ethnobotanical research were combined with that of NACOULMa OUEDRAOGO (1996); China: YANG (2006); Germany: all species named as MAP in the Flora of Germany (OBERDORFER 2001) and all species listed in particular books on Germany's medicinal plants (WICHTL 2002, SCHÖNFELDER \& SCHÖNFELDER 2004, VAN WYK et al. 2004) in relation to the total number of native and naturalised species (OBERDORFER 2001; apomictic aggregates were rated as one species); Great Britain and Ireland: all species listed by ALLEN \& HATFIELD (2004) in relation to the total number of native and naturalised species (based on ClaPHAM et al. 1993); India: JAIN \& DeFILlipPS (1991); Jordan: Oran \& Ali-EISAWI (1998); Nepal: HAMILTON \& RADFORD (2007): mean of several estimations; Pakistan: ZaHOoR (1997); USA: MoERman (1996); All other countries: SCHIPMANN et al. (2006)

Sources: Bénin: Sieglstetter (2002); Bulgarie: Hardalova et al. (1998); Burkina Faso: les résultats de nos propres recherches ethnobotaniques à l'échelle nationale ont été combinés à ceux de NACOULma OuÉDRAOGo (1996); Chine: YANG (2006); Allemagne: toutes les espèces désignées comme MAP dans la Flore de l'Allemagne (OBERDORFER 2001) et toutes les espèces énumérées dans les livres particuliers sur les plantes médicinales de l'Allemagne (WICHTL 2002, SCHÖNFELDER ET SCHÖNFELDER 2004, VAN WYK et al 2004.) par rapport au nombre total d'espèces locales et exotiques (OBERDORFER 2001; les agrégats apomictiques ont été considérés comme une espèce); grandeBretagne et l'Irlande: toutes les espèces énumérées par ALLEN ET HATFIELD (2004) par rapport au nombre total d'espèces locales et exotiques (sur la base de Clapham et al 1993.); Inde: JaIN \& DeFillipps (1991); Jordanie: Oran et Ali-Eisawi (1998); Népal: Hamilton \& RADFORD (2007): moyenne de plusieurs estimations, Pakistan: ZAHOOR (1997); USA: MoERman (1996); Tous les autres pays: Schipmann et al. (2006). 


\section{Discussion}

As the world's number of species is not exactly known (GoVAERTS 2001), it makes no sense to calculate the absolute number of MAP. The relative number is more correct and nevertheless impressing. Therefore, in the following, we only discuss the relative number.

The differences between some countries are striking: Calculated on a worldwide scale, every fifth plant can be regarded as MAP. This number matches that from Bulgaria, France and Germany. In countries like Benin, Burkina Faso, Korea, China and Pakistan, however, every third plant is or was used as MAP, whereas in countries like Hungary and the USA only every eighth plant can be regarded as MAP. This number drops even further for the Philippines ore Malaysia where only every tenth or thirteenth plant can be attributed to medicinal or aromatic use. These differences might be due to various factors like:

- geographical position of the country,

- total species number of the country,

- importance of folk medicine and in the level of transmission of traditional knowledge,

- intensity of the ethnobotanical research,

- level of the standard of the sources used for the review.

A geographical component of the results is obvious: in most cases geographically close countries show similar percentages (difference $<5 \%$ ) of MAP, as Benin and Burkina Faso, China and Korea, France and Germany, India and Sri Lanka, or Malaysia and the Philippines. As explained below, the difference between China and India shown in Table 1 is a result of differences in the standard of the source. Considering sources of equal standard, i.e. the referring volumes of the series "medicinal plants of the world", the figures for China (Duke \& AYENSU 1985: $15.3 \%$ ) and India (JAIN \& DeFilliPs 1981: $16.1 \%$ ), these countries show a difference $<1 \%$. The highest difference found between neighbouring countries under equal standards is $2.4 \%$. Furthermore a second geographical relation can be stated: Four of the five countries with a percentage of MAP > 30 are entirely or partially situated in semiarid to aorid regions, whereas the countries of temperate regions (except of Hungary and the USA; for potential reasons see below) show a range between $19.2 \%$ and $26.7 \%$.

In contrast to the locally obtained results of SALICK et al. (1999), a correlation between the total number of species and the fraction of those used as MAP cannot be confirmed: China, for example, amongst the countries considered ranks with respect to total species number highest, while the relative use of MAP ranks China at position four. The country with the second highest species number (USA), however, ranks third before last on this list. Malaysia, where the relative use of MAP is the smallest, ranks on position number four on the list of total species numbers. Nearly the opposite is true for Burkina Faso, which is poor in total plant species, but leading for MAP-use with a relative portion of $35.2 \%$. Hungary, showing a similar low number of species in total is the fourth before last on the list of percentages of MAP (12.2\%).
For the USA, the low percentage of MAP can be explained historically: The European settlers, the main founding community of today's American population, did not know the plant species of their new home country. They brought along those MAP they new as especially important from Europe. The knowledge of the indigenous nations primarily was not considered. With the diminishing of the native people and extinction of whole ethnics groups necessarily a part of their knowledge on MAP got irretrievably lost and cannot even be rediscovered by the large data base established by MoERMAN (1996).

The countries with percentage of MAP > $30 \%$ (Benin, Burkina Faso, P.R.China, Republic of Korea, Pakistan) have another feature in common: they belong either entirely (Burkina Faso, Benin) or at least in their rural areas to the poorest countries of the world so that it is (was) impossible for the majority of the people to buy "modern" MAP. In those countries the number of traditional healers outnumbers largely the number of modern doctors (Human DEvelopment REPORT 1990). Therefore, the tradition of folk medicine was maintained until today. Additionally, China, Korea and partially Pakistan have a very old and well documented tradition of folk medicine. Due to this documentation even in areas where today "modern MAP" are used, the knowledge was not lost. However, these arguments do not explain why China, Korea and Pakistan are so distinctive from Jordania, India, Nepal, Sri Lanka, Thailand and Vietnam.

In the European countries, which have an intermediate position in the ranking of the percentage of MAP, written records exist as well. However, the documents are not as old as in China so it cannot be excluded that some information was lost in the course of time. Malaysia and the Philippines have no written records on the traditions of folk medicine. Today, large parts of the population are concentrated in megalopolises where traditions probably get lost. For the rural areas it can be assumed that medicinal knowledge has not been documented to such an extent as in Burkina Faso, China and Korea.

In neighboring countries or regions, which differ with respect to a more arid or a more humid climate (Burkina Faso/Benin and northern China/southern China), for the arid country (region) more MAPs are reported than for the humid one. In China, the average MAP fraction of $36.2 \%$ (YANG 2002) is unequally distributed between the humid south and the dry northwest: In the semiarid province of Qinghai $58.6 \%$ of the species of vascular plants are used as MAP, in the humid province of Yunnan only $21.2 \%$. As these numbers stem from the same authors (SHEngur et al. 2006), one can be sure that this difference is not a result of different methods or different standards. Furthermore, the figure for Qinghai is confirmed by the referring percentage of $58.9 \%$ for the Autonomous Region of Ningxia (XING 2006), also belonging to the semi-arid region of China.

Some possible explanations for this fact are:

- In years of extreme dryness certain species totally drop out of the plant inventory, some get scarce (for example when cattle turns to devour plants usually avoided when the food supply is more abundant and diverse, some species are even hard to find). Therefore, in regions of po- 
tential dry periods, it is essential to know some species, which can be used as substituent when the most effective medical plant species is not available. In areas of a balanced climate, particularly in the core tropics, there is no danger of species dropping out by climatic reasons. In such countries it is sufficient to know only the most effective MAP for a particular malady.

- In the humid tropics the species number is much higher than in arid regions. Therefore, assuming that a certain number of species is needed to fill all therapeutic demands (see e.g. Alencar et al. 2009), in the humid tropics the proportion of medicinal plants should be smaller than in arid areas.

- In arid and semiarid regions, pasture pressure on plants is higher than in humid areas. For this reason, plant species have to develop means of defense against being devoured, e.g. phenolics (TuOMI et al. 1991, HartLEY \& LAWTON 1991), and especially those are important sources of MAP (e.g. Fernandes et al. 2009, HuAng et al. 2010).

- Under conditions of drought, cells accumulate sugar, abscisic acid and some particular alkaline proteins (HsIAO 1973). Although these substances are not particularly known as medicinally active, one cannot exclude that a combined effect of them may be of medicinal efficiency (e.g. GeNG et al. 2001).

- Often the roots of plants are the basis of MAP, but even plants of the same species tend to show stronger root growth and or an increased shoot/root ratio in dry habitats (KUTSCHERA 1960).

A very important reason for the difference between neighboring countries is the standard of the source. This can differ in the following items:

- Threshold for species mentioned: are all species listed that have been used as medicinal plants or only those which appear to be worth of an industrial use or of a world wide trade?

- Completeness of the survey: were all areas of the country considered?

- Intensity of the survey: Most healers are very suspicious against strangers, in particular foreigners. It needs a long time (at least some weeks, often some months or even years) to get their confidence. Therefore, a country wide survey based on short visits of experts will result in a much lower number of MAP than a survey with long lasting stays in the areas under investigation.

The different numbers given for China by Duke \& AYEnsu (1985: $15.3 \%$ ) and by YANG (2002: $36.2 \%)$ witness the importance of the source: The first authors contribute to a volume of the series Medicinal Plants of the World which considers only species of more or less world wide interest, while the latter author has tried to summarize all information and has considered even species only rarely used. These findings solve the above mentioned contradiction of a highly different percentage of MAP in the neighboring countries China and India. For India we found no local source and therefore had to use the respective volume of Medicinal
Plants of the World (JAIN \& DeFILLIPPS 1991). If we consider this series for both countries, we find rather identical percentages (China: $15.3 \%$; India: $16.1 \%$ ). Vice versa we postulate that the "real" number of MAP for India also resembles that one of China, i.e amounts to about $35 \%$.

Another striking example for the importance of the source is Benin: without own field research we would have to rely on the "official" list of Benin's MAP (ADJANOHOUN et al. 1989), which contains 507 species representing only $18.1 \%$ of the flora. This number was found by an officially announced expert group that visited every province for three or four days. In contrast, our investigator (Sieglstetter) stayed three times for three months in an area consisting of three villages and carried out his ethnobotanical research during the second and third stay, while the first stay was used to become acquainted with local people and to obtain their confidence. Since percentages given in Table 1 for Malaysia, The Philippines, Sri Lanka and Thailand also originate from overviews or short-surveys, but not from intensive long-lasting ethnobotanical research, they also can be estimated as an underrepresentation. Additionally, at least for some of the countries showing low values in Table 1, it is fair to assume that not all remote areas are investigated in detail.

\section{CONCLUSION}

For many countries the percentage given for MAP in literature is to low. But even using these low values every fifth vascular plant species is or was used as MAP. In tropical countries, particularly in semiarid regions, even every third species was used. The example of northern China shows that even every second species might represent a MAP. Assuming that plants in regions of equal ecological character have more or less the equal traits, we can conclude that in (semi)arid regions the average percentage of MAP amounts to about $35 \%$, while in temperate regions it reaches about $22 \%$. This assumption leads to a world-wide percentage of 25 to $30 \%$, i.e. every third or fourth plant species is a MAP. But, no matter whether we take this assumption as reality or if we rely on the published data shown in Table 1, the number of MAP is higher than estimated up to now. It represents a striking argument for the importance of a worldwide conservation of biodiversity.

\section{References}

Adjanohoun EJ, Adjakidje V, Ahyi MRA, Ake Assi L, Akoegninou A, D'Almeida J, Apovo F, Boukef K, CHadre M, Cusset G, Dramane K, Eyme J, Gassita J-N, Gbaguidi N, Goudote E, Guinko S, Houngnon I, Lo, Keita A, Kiniffo HV, Kone-Bamba D, Musampa Nseyya A, SaAdou M, Sodogandui T, de Souza S, Tchabi A, Zinsou C, Dossa, T. Zohoun T (1989): Contribution aux Etudes Ethnobotaniques et Floristiques en République Populaire du Bénin. France Agence de Cooperation Culturelle et Technique (ACCT), Paris.

Alencar NL., De Sousa Araújo TA, Cavalcanti de AmoRIM EL, AlbuQueroue UP. (2010): The Inclusion and Selection of Medicinal Plants in Traditional Pharmacopoeias - Evidence in Support of the Diversification Hypothesis. Econ Bot 64:68-79. 
Allen DE, Hatfield G (2004): Medicinal Plants in Folk Tradition - An Ethnobotany of Britain , and Ireland. Timber Press, Portland Cambridge.

Balmford A., Bruner A, Cooper P, Costanza R, Farber S, Green RE, Jenkins M, JefFeriss P, Jessamy V, Madden J, Munro K, Myers N, Naeem S, Paavola J, Rayment M, Rosendo S, Roughgarden J, Trumper K, Turner KR. (2002): Economic reasons for conserving wild nature. Sci 297: 950-953.

Bogers RJ, Craker LE, Lange D (2006) (eds.): Medicinal and Aromatic Plants. Springer, Wageningen.

Caniago I, Siebert S F (1998): Medicinal Plant Ecology, Knowledge and Conservation in Kalimantan, Indonesia. Econ Bot 52:229-250.

Clapham AR, Tutin TG, Warburg EF (1993): Excursion Flora of the British Isles, 3rd ed. Cambridge University Press.

Costanza R., D'Arge R, de Groo R, Farber S, Grasso M, Hannon B, Limburg K, Naeem S, O’Neill RV, Paruelo J, Raskin RG, Sutton P, van den Belt M. (1997): The value of the world's ecosystem services and natural capital. Nature 387: 253-260.

Craker LE, Gardner ZE (2006): Medicinal plants and tomorrow's pharmacy. In: Bogers RJ, CRAKER LE, LANGE D (eds.): Medicinal and Aromatic Plants. Springer, Wageningen, 29-41.

Duke JA, Ayensu ES (1985): Medicinal plants of China. Reference Publications, Algonac (Michigan).

European Communities (2008): The economics of ecosystems and biodiversity. Banson, Cambridge.

Fernandes A, Fernandes I, Cruz L, Mateus N, Cabral M, DE Freitas V (2009): Antioxidant and biological properties of bioactive phenolic compounds from Quercus suber L. J. Agric. Food. Chem. 57:11154-60.

Geng P, Yang Y, Gao Z, Yu Y, Shi Q, Bai G (2007): Combined effect of total alkaloids from Feculae Bombycis and natural flavonoids on diabetes. J. Pharm. Pharmacol. 59:1145-50.

GovaERTs R (2001): How many species of seed plants are there? Taxon 50:1085-1090.

HAMilton A, RADFORD E (2007): Identification and conservation of important plant areas for medical plants in the Himalaya. Plantlife, Salisbury.

Hardalova R, Evstatieva L, Gussev C (1998): Wild medicinal plant resources in Bulgaria and recommendations for their longterm development. In: C. MeInE C (ed.): Bulgarias's biological diversity: conservation status and needs assessment. Vol 1 and 2. Biodiversity Support Programme, Washington DC, 527-561.

Hartley SE, Lawton JH (1991): Biochemical aspects and significance of the rapidly induced accumulation of phenolics in birch foliage. Pages In: Tallamy DW, RaupP MJ (eds.): Phytochemical induction by herbivores. Wiley, New York, 105-132

Health Canada (ed.). 2001. Perspectives on complementary and alternative health care. A collection of papers prepared for Health Canada, Ottawa.

Hsiao TC (1973): Plant responses to water stress. Ann Rev Plant Physiol 24:519-570.
HuANG W, CAI YZ, ZHANG Y (2010): Natural phenolic compounds from medicinal herbs and dietary plants: potential use for cancer prevention. Nutr. Cancer. 62:1-20.

Human Development Report (1990): Concept and Measurement of Human Development. Human Development Report Office, New York.

JAIN SK, DeFillipps RA (1991): Medicinal plants of India. Vol. 1. Reference Publications, Algonac (Michigan).

Kayne SB (2010) (ed.): Traditional medicine. Pharmaceutical Press, London.

KUTSCHERA L (1960): Wurzelatlas mitteleuropäischer Ackerunkräuter und Kulturpflanzen. DLG, Frankfurt/M.

LEJoly J (1993): Situation en 1993 de PHARMEL, banque de données sur les plantes africaines utilisées en médecine traditionnelle GRANCHER M (ed.): La plante médicinale de la tradition à la science. 1er Congrès intercontinental - Tunis. Plantes médicinales et phytothérapie, 39-45

Lewis WH (2003): Pharmaceutical Discoveries Based on Ethnomedicinal Plants: 1985 to 2000 and Beyond. Econ Bot 57:126-134.

Marstedt G, S. Moebus S (2002): Inanspruchnahme Alternativer Methoden in der Medizin. Gesundheitsberichte des Bundes 9. Robert Koch Institut, Statistisches Bundesamt, Berlin.

Millenium Ecosystem Assessment (2005): Ecosystems and human well-being: biodiversity synthesis. World Resources Institute, Washington DC

Moerman DE (1996): An analysis of the food plants and drug plants of native North America. J. Ethnopharmacol 52:1-22.

Nacoulma Ouedraogo OG (1996): Plantes médicinales et pratiques médicinales traditionnelles au Burkina Faso. Cas du plateau central. Thèse Doctorat d'Etat es Sciences. Univ. Ouagadougou. Vol 1, 2.

Newman DJ, CragG GM, SNader KM (2003): Natural products as sources of new drugs over the period 1981-2002. J. Natural Products 66:1022-1037.

OBERDORFER E (2001): Flora von Deutschland. Ulmer, Stuttgart.

Oran SA, Ali-Eisawi DM (1998): Checklist of medicinal plants of Jordan. Dirasat. Med. Biol. Sci. 25(2): 84-112.

Prajapati ND, Prajapati T, JaJPURA S (2005): Advances in medicinal plants. Vol. 1. Asian Medicinal Plants and Health Care Trust, Jodhpur.

Rao GP, Patil SK, Prabhuji SK. (2005) (eds.): Recent Advances in Medicinal Plants Research. Satish Serial Publ., New Delhi.

Salick J, Bium A, Martin G, Apin L (1999) Whence useful plants ? A direct relationship between biodiversity and useful plants among the Dusun of Mt. Kinabualu. Biodiversity Conservation 8: 797-818.

Schippmann U, Leamann D, Cunnigham AB (2006): A comparison of cultivation and wild collection of medicinal and aromatic plants under sustainibility aspects. In: BoGERS RJ, Craker LE, Lange D (eds.): Medicinal and aromatic plants, Springer, 75-95.

SCHÖNFELDER I, P. SCHÖNFELDER P (2004): Das neue Handbuch der Heilpflanzen. KOSMOS Verlag, Stuttgart.

Shengui P, Huying H, Lixin Y. (2006): Important plant areas for medicinal plants in Chinese Himalaya. In: National 
Report Regional workshop on identification and conservation of important plant areas for medicinal plants in the Himalayas 19-22, September, 2006, Kathmandu, Nepal, 1-24

Sieglstetter R (2002): Wie die Haare der Erde - Vegetationsökologische und soziokulturelle Untersuchungen zur Savannenvegetation der Südsudanzone Westafrikas und ihrer Nutzung und Wahrnehmung durch die ländliche Bevölkerung am Beispiel der Region Atakora im Nordwesten Benins. Diss. FB Biowissenschaften, Goethe-Universität, Frankfurt.

Sofowara A (1996): Research on medical plants and traditional medicine in Africa. J. Alternative Complementary Med 2:365-372.

The Delegates of the Conference on Traditional MeDICINE IN ASEAN CounTRIES (2009): Bangkok declaration on traditional medicine. Bangkok.

Thomas, KJ, Nicholl JP, Coleman P (2001): Use and expenditure on complementary medicine in England: a population based study. Complement. Ther. Med. 9:2-11.

Tuomi J, Niemelä P, FAgerström T (1991): Carbon allocation, phenotypic plasticity and inducible defences. In: TALLAMY DW, RAupP MJ (eds.): Phytochemical induction by herbivores. Wiley, New York, 85-104.

UNDP (1993): Human development report. OUP, New York

VAn WyK, B-E, Wink C, Wink E (2004): Handbuch der Arzneipflanzen. Wissenschaftliche Verlagsgesellschaft, Stuttgart.

WeCKerle CS, Huber FK, YongPing Y, Weibang S (2006): Plant Knowledge of the Shuhi in the Hengduan Mountains, Southwest China. Econ Bot 60:3-23.

Wichtl M (2002) (ed.): Teedrogen und Phytopharmaka, ein Handbuch für Apotheker und Ärzte, 4. Aufl. Wissenschaftliche Verlagsgesellschaft, Stuttgart.

Wittig R, Hahn K, Krohmer J, Müller J (2000): Nutzung, Degradation und Regeneration von Flora und Vegetation in westafrikanischen Savannenlandschaften. Ber Reinhold-Tüxen Ges 12: 263-281.

Wittig R, Hahn K, Krohmer J, Müller J, Sieglstetter R (2002): La végétation actuelle des savanes du Burkina Faso et du Bénin - sa signification pour l'homme et la modification de celleci par l'homme (aperçu des résultats d'un projet de recherche duré des années). Etudes flor veg Burkina Faso 7: 3-16.

Wittig R, Guinko S, Hahn K, Sinsin B, Zizka G, DressLER S, Thiombiano A (2009): Twenty Years of Cooperation between Botanists of the Goethe-University Frankfurt (Germany) and of West African Universities. Flora Veg SudanoSambesica 12:5-21.

XING S (2006): The Medicinal Plants of Ningxia (in Chinese). Ningxia Peoples Publishing House, Yinchuan.

YANG S (2002): Plant Biology (in Chinese). Science Press. Beijing.

ZaHOOR A (1997): Medicinal plants of Pakistan. In: KraKI M, Rao AN, Ramanantha RaO V, Williams JT (eds.): The role of bamboo, rattan and medicinal plants in mountain development. Proceedings of a workshop held at the Institute of Forestry, Pokhara, Nepal, 15.-17. May 1996. International Development Research Centre, New Delhi. IINBAR Technical Report 1:207-214.

\section{ADDRESSES OF THE AUTHORS:}

Prof. Dr. Theo Dingermann ${ }^{1}$, Dr. Karen Hahn $^{2.3}$, Dr. Robert Sieglstetter ${ }^{2}$, Prof. Dr. Adjima Thiombiano ${ }^{4}$, Prof. Dr. Rüdiger Wittig $^{* 2,5}$ and Prof. Dr. Yingzhong $\mathrm{Xie}^{6}$

${ }^{1}$ Institute for Pharmaceutical Biology, Goethe-University, 60438 Frankfurt, Germany

${ }^{2}$ Abteilung Ökologie und Geobotanik. Insititut für Ökologie, Evolution und Diversität, Goethe-Universität, 60323 Frankfurt, Germany

${ }^{3}$ Zentrum für interdisziplinäre Afrikaforschung (ZIAF), Goethe-Universität, 60323 Frankfurt, Germany

${ }^{4}$ Sciences de la Vie et de la Terre, Laboratoire de Biologie et Ecologie Végétales, Université de Ouagadougou, 03 BP 7021 Ouagadougou, Burkina Faso

${ }^{5}$ Biodiversitäts- und Klima-Forschungszentrum (BiK-F), 60325 Frankfurt, Germany

${ }^{6}$ Institute of Grassland Sciences, Ningxia University, China

${ }^{*}$ Corresponding author; e-mail: r.wittig@bio. uni-frankfurt.de 